\title{
Rapid diagnosis of extra pulmonary tuberculosis by automated Xpert MTB/RIF assay
}

\author{
Shirly Suzana, Baby Shalini, Priscilla Rupali, K Venkatesh, DJ Christopher, Joy S Michael* \\ From First International Science Symposium on HIV and Infectious Diseases (HIV SCIENCE 2012) \\ Chennai, India. 20-22 January 2012
}

\section{Introduction}

Although extra pulmonary tuberculosis accounts for only $10-15 \%$ of tuberculosis in India, they have high morbidity and mortality because of lack of good diagnostic methods. One of the recent molecular methods namely the Xpert MTB/RIF is a fully automated real time PCR system that detects M. tuberculosis (Mtb) complex and rifampicin resistance directly from clinical samples. This assay has been extensively evaluated in the diagnosis of pulmonary tuberculosis. The purpose of this study was to test the efficiency of this assay for the rapid and reliable diagnosis of extra pulmonary tuberculosis (EPTB).

\section{Materials and methods}

This was a pilot prospective blinded study done on 60 samples received in the department of Microbiology from patients with signs and symptoms of EPTB. All the samples were tested by Xpert MTB/RIF as well as routine conventional smear and culture.

\section{Results}

Overall the sensitivity, specificity, PPV and NPV of Xpert MTB/Rif assay in detecting $M$. tuberculosis from clinical samples was $86 \%, 100 \%, 100 \%$ and $83 \%$ respectively.

In the drug susceptibility testing (DST) there was $100 \%$ correlation between rifampicin susceptibility pattern between Xpert MTB/RIF assay and DST by MGIT/ LJ method. The mean turnaround time by Xpert MTB/ Rif assay was 2 hours when compared to culture and DST by LJ and MGIT systems were 46 days and 15 days respectively.

\section{Conclusion}

The Xpert MTB/RIF is a rapid and reliable diagnostic assay for detection of Mycobacterium tuberculosis and rifampicin resistance in EPTB samples.

Published: 4 May 2012

doi:10.1186/1471-2334-12-S1-P32

Cite this article as: Suzana et al.: Rapid diagnosis of extra pulmonary tuberculosis by automated Xpert MTB/RIF assay. BMC Infectious Diseases 2012 12(Suppl 1):P32.

* Correspondence: joymichael@cmcvellore.ac.in

Department of Microbiology, Christian Medical College, Vellore, India

Submit your next manuscript to BioMed Central and take full advantage of:

- Convenient online submission

- Thorough peer review

- No space constraints or color figure charges

- Immediate publication on acceptance

- Inclusion in PubMed, CAS, Scopus and Google Scholar

- Research which is freely available for redistribution
C Biomed Central 